\title{
The Lexicon-Grammar of Italian Idioms
}

\author{
Simonetta Vietri \\ Department of Political, \\ Social and Communication \\ Sciences \\ University of Salerno, Italy \\ vietri@unisa.it
}

\begin{abstract}
This paper presents the Lexicon-Grammar classification of Italian idioms that has been constructed on formal principles and, as such, can be exploited in information extraction. Among MWEs, idioms are those fixed constructions which are hard to automatically detect, given their syntactic flexibility and lexical variation. The syntactic properties of idioms have been formally represented and coded in binary matrixes according to the Lexicon-Grammar framework. The research takes into account idioms with ordinary verbs as well as support verb idiomatic constructions. The overall classification counts 7,000+ Italian idioms. In particular, two binary matrixes of two classes of idioms will be presented. The class $\mathbf{C 1}$ refers to the Verb + Object constructions, whereas the class EPC refers to the prepositional constructions with the support verb essere. Pre-constructed lexical resources facilitate idioms retrieval both in the case of "hybrid" and "knowledge-based" approaches to Natural Language Processing.
\end{abstract}

\section{Introduction}

Idioms, and multi-word expressions in general, have always been "a pain in the neck", as Sag et al. (2001) state in the title of their paper. The formal representation and the construction of a computational linguistic model of idioms is not an easy task as shown by Gazdar et al. (1985), Pulman (1993), Abeillé (1995), Villavicencio et al. (2004), Muzny and Zettlemoyer (2013) to name a few of the many (computational) linguists who have carried out research on this topic.

It has always been pointed out that the main problem concerning the automatic analysis of idioms is the difficulty to disambiguate such constructions which are ambiguous by definition (Fothergill and Baldwin 2012, Li and Sporlender 2009, Fazly et al. 2009, McShane and Nirenburg 2014). However, given the flexibility of idioms, a more basic and still unsolved problem has to be taken into account: that is, the extraction and annotation of such constructions (Fellbaum 2011).

As Fazly et al. (2009, p. 61) point out "despite a great deal of research on the properties of idioms in the linguistics literature, there is not much agreement on which properties are characteristics of these expressions". The distinction drawn by Nunberg et al. (1994) between idiomatic phrases and idiomatically combining expressions has been adopted by most of the research on idioms. However, many problems still remain and they are due to two basic reasons. On one hand, idioms can be considered lexical units, given the fact that their "special meaning" is associated to a particular verb and one or more particular complements. On the other hand, idioms syntactically behave as non-idiomatic constructions. Passive is the syntactic construction more frequently analyzed by the linguistic research on idioms since it involves the occurrence of the fixed object to the left of the verb. However, idioms show a great deal of other syntactic constructions where the fixed object may not necessarily occur in postverbal position (see Vietri 2014, forthcoming).

It is for these peculiarities that idioms have also aroused the interest of the psycholinguistic researchers who have advanced several hypothesis on the processing of idioms (Swinney and Cutler,

This work is licensed under a Creative Commons Attribution 4.0 International Licence. Page numbers and proceedings footer are added by the organisers. Licence details: http://creativecommons.org/licenses/by/4.0/. 
1979; Gibbs, 1995; Cacciari and Tabossi, 1988; Cutting and Bock, 1997; Sprenger et al., 2006).

The systematic description of French idiomatic and non-idiomatic constructions has been carried out by Gross $(1982,1988)$ and his colleagues (Leclère, 2002) on the basis of the formal principles of the Lexicon-Grammar methodology, as developed by Gross $(1975,1979)$. According to Gross, the basic syntactic unit is not the word but the simple or elementary sentence, and the Lexicon-Grammar of a language is organized into three main components: free sentences, frozen sentences (or idioms), support verbs sentences (Gross 1981, 1998). For each component, Gross and his colleagues built exhaustive classifications, systematically organized and represented by binary matrixes (named LexiconGrammar tables), where each syntactic and/or distributional property is marked "+" or "-" if accepted or not by a certain lexical unit. In the Lexicon-Grammar methodology, idiomatic and non-idiomatic constructions are built according to the same formal principles. The difference between these two types of constructions mainly concerns the distribution: idioms show a higher level of restricted distribution than non-idioms. The French Lexicon-Grammars are available at http://infolingu.univmlv.fr/english/.

A classification of English idioms and phrasal verbs has been carried out according to the same formal principles and criteria, respectively, by Freckleton (1985) and Machonis (1985). A LexiconGrammar of European Portuguese idioms has been built by Baptista (2005a, 2005b).

The Lexicon-Grammar classification of Italian idioms has been implemented on the basis of Gross' methodology. It includes more than 30 Lexicon-Grammar classes of idioms with ordinary verbs (sec. 2 ) and support verbs (sec. 3), for a total of more than 7,000 lexical entries ${ }^{1}$. The binary matrixes are created in Excel format.

\section{The Lexicon-Grammar of Italian Idioms with Ordinary Verbs}

The Lexicon-Grammar of idioms using ordinary verbs includes 12 classes for a total of 3,990 entries (sec. 2.1, Table 1). Each class of idioms contains those constructions which share the same definitional structure. In the Lexicon-Grammar framework, the definitional structure is identified on the basis of the arguments required by the operators (see Harris 1982). In the case of idioms, the operator consists of the Verb and the Fixed element(s), while the argument may be the subject and/or a free complement. This section shows only the main differences between the idioms' classes $\mathbf{C 1}$ and $\mathbf{C A N}$.

For example, idioms in (1) and (2) have two different definitional structures. On one hand, an idiom such as tagliare la corda in (1) is an operator that requires only one argument, i.e. the subject. On the other hand, an idiom such as rompere le balle in (2) is an operator that requires two arguments, the subject and the noun Amy within the prepositional complement. The prepositions $a$ and $d i$ alternate and can be considered fixed:

1. Amy ha tagliato la corda

Amy-has-cut-the-rope

2. "to sneak off"

"to annoy sb."

Idioms such as (1) have been listed and analyzed in a class named $\mathbf{C 1}$, that counts about 1,200 entries. Furthermore, $\mathbf{C}$ indicates the "constrained" or "fixed" noun and $\mathbf{1}$ refers to its position in the sentence, in this case, the object position. These idioms have only one argument, that is the (non-fixed noun) in subject position. The definitional structure of the class $\mathbf{C} \mathbf{1}$ is $\mathbf{N}_{\mathbf{0}} \mathbf{V} \mathbf{C}_{\mathbf{1}}$ where $\mathbf{N}$ indicates the free noun, $\mathbf{V}$ the verb and $\mathbf{C}$, as previously stated, the fixed element. The subscripts $\mathbf{0}$ and $\mathbf{1}$ indicate the position of the noun within the sentence in a linear order, in this case, the subject and the object position.

Idioms such as (2) have been listed and analyzed in the class named CAN, that counts 320 entries. The definitional structure of this class is $\mathbf{N}_{\mathbf{0}} \mathbf{V} \mathbf{C}_{\mathbf{1}}(\mathbf{a}+\mathbf{d i}) \mathbf{N}_{\mathbf{2}}$, since these idioms have two arguments,

\footnotetext{
${ }^{1}$ Vietri (1984) includes the very first classification of Italian idioms. Since then, the classification has been widely enriched, updated and completely re-examined. For a semantic study of Italian idioms, see Casadei (1996). A LexiconGrammar classification of Verb-particle constructions has been developed by Guglielmo (2013). From a different perspective, Masini (2005) provides a synchronic and diacronic analysis of Italian verb-particle constructions found in a corpus.
} 
i.e. the subject $\mathbf{N}_{\mathbf{0}}$ and the noun $\mathbf{N}_{\mathbf{2}}$. The alternation of the prepositions $a$ and $d i$ is represented between brackets, and the "+" sign indicates "either/or".

Each class, formally represented by a table in the form of a binary matrix, contains a specific number of idiomatic entries associated with a specific number of distributional and syntactic properties. In particular, each row of the matrix corresponds to an idiom, and each column to a property (or a construction). If the idiom accepts that particular property, a "+" sign is placed at the intersection between the row and the column; otherwise a "-" sign occurs.

As a sample of this type of lexical resource, I will give an excerpt of the class $\mathbf{C 1}$ in Figure 1. The central non-numbered columns indicate the "part of speech" assigned to each lexical element that constitutes the idiomatic construction. In an idiom like non alzare un dito (lit. not lift a finger), the negation non is obligatory. On the other hand, the si-pronominal form is obligatory in idioms like leccarsi $i$ baffi (lit. lick-si the moustaches). The determiner can be Definite (Def), Indefinite (Ind), or null (Zero). As previously pointed out, $\mathbf{V}$ refers to the verb and $\mathbf{C}$ to the fixed noun.

The properties from [1] to [3] indicate the distribution of $\mathbf{N}_{\mathbf{0}}$, i.e. the subject. It can be expressed by [ \pm human] noun or a by a sentence [Ch F].

The distributional property [4] indicates if $\mathbf{C}_{\mathbf{1}}$ is expressed by a body-part noun, whereas the morphological property [5] indicates if $\mathbf{C}_{\mathbf{1}}$ can be in the plural form. Property [4] showed that 1,700+ idioms involve a body-part noun, at least the $24 \%$ of the overall classification. Property [5] is a useful piece of information because it refers to the possible variation of the fixed noun and, consequently, of the determiner.
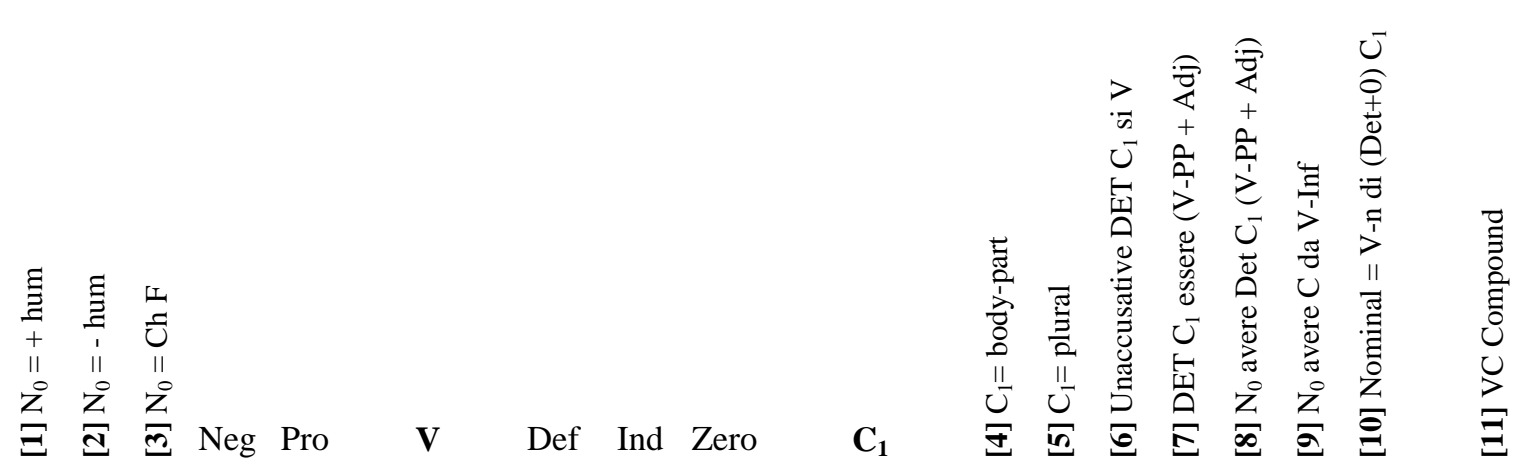

\begin{tabular}{|c|c|c|c|c|c|c|c|c|c|c|c|c|c|c|c|c|c|}
\hline+ & - & - & - & - & allungare & il & - & - & muso & + & - & - & - & + & - & - & - \\
\hline+ & - & - & non & - & alzare & - & un & - & dito & + & - & - & - & - & - & - & - \\
\hline+ & - & - & - & - & alzare & la & - & - & testa & + & - & - & - & + & - & + & - \\
\hline+ & - & - & - & - & chiudere & il & - & - & capitolo & - & - & + & + & - & + & - & - \\
\hline+ & - & - & - & - & dipanare & la & una & - & matassa & - & - & + & + & - & + & - & - \\
\hline+ & - & - & - & - & incrociare & le & - & - & braccia & + & - & - & + & + & - & - & - \\
\hline+ & - & - & - & - & ingoiare & il & un & - & rospo & - & + & - & - & - & + & - & - \\
\hline+ & - & - & - & si & leccare & $\mathrm{i}$ & - & - & baffi & + & - & - & - & - & - & + & - \\
\hline+ & - & - & - & si & mangiare & il & - & - & fegato & + & - & - & - & - & - & - & - \\
\hline+ & - & - & - & si & mangiare & la & - & - & lingua & + & - & - & - & - & - & - & - \\
\hline+ & + & + & - & - & mostrare & la & - & - & corda & - & - & - & - & - & - & - & - \\
\hline+ & - & - & - & - & perdere & il & - & + & tempo & - & - & - & - & - & + & + & perditempo \\
\hline+ & - & - & - & - & rizzare & gli & - & - & orecchi & + & - & - & + & + & - & - & - \\
\hline+ & - & - & - & - & rompere & il & - & - & ghiaccio & - & - & + & + & - & - & - & - \\
\hline+ & - & - & - & - & scoprire & $\mathrm{l}^{\prime}$ & - & - & acqua calda & - & - & - & - & - & - & + & - \\
\hline+ & - & - & - & - & scoprire & le & - & - & carte & - & - & - & + & + & + & - & - \\
\hline+ & - & - & - & - & scoprire & $\mathrm{l}^{\prime}$ & - & - & America & - & - & - & - & - & - & + & - \\
\hline+ & - & - & - & - & tappare & il & un & - & buco & - & + & - & - & - & + & - & tappabuchi \\
\hline+ & - & - & - & - & vendere & - & - & - & fumo & - & - & - & - & - & + & - & vendifumo \\
\hline
\end{tabular}

Figure 1. The Class C1 
The syntactic properties are numbered from [6] to [10]. In particular, [6] and [7] refer, respectively, to the unaccusative (3b) and the adjectival passive (3c) constructs in which some idioms may occur, as in the following:
3a. Liv ha dipanato la matassa
"to solve a problem"
3b. La matassa si è dipanata
The skein-si-is-unraveled
3c. La matassa è dipanata
The-skein-is-unraveled

Properties [8] and [9] indicate two more sentence structures in which idioms may occur. In particular, [8] refers to a sentence structure involving the verb avere ('to have') as in (4b):
4a. $\quad$ Gli operai incrociano le braccia
"to go on strike"
4b. $\quad$ Gli operai hanno le braccia incrociate
The-workers-have-the-arms-crossed

The syntactic property [9] indicates a particular structure where the verb is in the infinitive form and introduced by the preposition $d a$, as in (5b):
5a. Joe ingoiò un rospo
Joe-swalled-a-toad
"to swallow a bitter pill"
5b. Joe ha un rospo da ingoiare
Joe-has-a-toad-to-swallow

Notice that, in the constructions defined by properties [6]-[9], $\mathbf{C}_{\mathbf{1}}$ does not occur in its canonical position but to the left of the verb.

Property [10] concerns the possibility of having a nominalization, as in (6b). Finally, the morphosyntactic property [11] shows the formation of a VC compound, as in (7b). The VC compound is explicitly indicated in the corresponding column.
6a. Joe ha alzato la testa
"to rebel"
6b. L'alzata di testa (di + che ha fatto) Joe
Joe-has-raised-the-head
The-raising-of-the-head (of + that-has-made)-Joe
7a. Joe vende fumo
Joe-sells-smoke
"to be a snake oil salesman"
7b. Joe è un vendifumo
Joe-is-a-sell.smoke

\subsection{The Classes of Idioms with Ordinary Verbs}

Table 1 contains all the classes of idioms with ordinary verbs. The first column indicates the name of the Lexicon Grammar class, while the second column refers to the definitional structure of the idioms belonging to the corresponding class. The third column contains an idiomatic example for each class. Finally, the fourth column refers to the number of idioms listed in each class. The last class of Table 1, i.e. PVCO, contains those idioms where the fixed verb is followed by a comparative clause introduced by come $e^{2}$.

The figures in the fourth column are to be taken as an approximate quantity, since this is an ongoing research. Therefore, the classes are subject to updating. Although approximate, the figures are an important piece of information because they show the idioms' distribution throughout the syntactic patterns.

\footnotetext{
${ }^{2}$ See also De Gioia (2001).
} 


\begin{tabular}{|c|c|c|c|}
\hline LG-class & Sentence structure & Example & $\mathbf{N}$. \\
\hline CO & $\mathrm{C}_{0} \mathrm{~V} \Omega$ & il piatto piange & 80 \\
\hline C1 & $\mathrm{N}_{0} \mathrm{~V} \mathrm{C}_{1}$ & tirare le cuoia & 1,200 \\
\hline CAN & $\mathrm{N}_{0} \mathrm{~V} \mathrm{C}_{1}(\mathrm{a}+\mathrm{di}) \mathrm{N}_{2}$ & rompere le scatole $(a+d i) N$ & 320 \\
\hline CDN & $\mathrm{N}_{0} \mathrm{~V} \mathrm{C}_{1}$ di $\mathrm{N}_{2}$ & non vedere l'ora di $N$ & 90 \\
\hline CPN & $\mathrm{N}_{0} \mathrm{~V} \mathrm{C}_{1}$ Prep $\mathrm{N}_{2}$ & attaccare bottone con $N$ & 550 \\
\hline CPC & $\mathrm{N}_{0} \mathrm{~V} \mathrm{C}_{1}$ Prep $\mathrm{C}_{2}$ & prendere lucciole per lanterne & 450 \\
\hline CPCPN & $\mathrm{N}_{0} \mathrm{~V} \mathrm{C}_{1}$ Prep $\mathrm{C}_{2}$ Prep $\mathrm{N}_{3}$ & dire pane al pane a $N$ & 20 \\
\hline NPC & $\mathrm{N}_{0} \mathrm{~V} \mathrm{~N}_{1}$ Prep $\mathrm{C}_{2}$ & piantare $N$ in asso & 350 \\
\hline PCPN & $\mathrm{N}_{0} \mathrm{~V}$ Prep $\mathrm{C}_{1}$ Prep $\mathrm{N}_{2}$ & dare alla testa a $N$ & 100 \\
\hline PC1 & $\mathrm{N}_{0}$ V Prep $\mathrm{C}_{1}$ & parlare al muro & 600 \\
\hline PCPC & $\mathrm{N}_{0} \mathrm{~V}$ Prep $\mathrm{C}_{1}$ Prep $\mathrm{C}_{2}$ & durare da Natale a Santo Stefano & 30 \\
\hline \multirow[t]{2}{*}{ PVCO } & $\mathrm{N}_{0} \mathrm{~V}$ come $\mathrm{C}_{1}$ & fumare come un turco & 200 \\
\hline & & & 3,990 \\
\hline
\end{tabular}

Table 1. Idioms with Ordinary Verbs

\section{The Lexicon-Grammar of the Italian Idiomatic Support Verb Constructions}

Idioms may be not only formed by an ordinary verb but also by support verbs, the most common of which are, in Italian, avere ('to have'), essere ('to be'), fare ('to make'). The main difference between support verbs (hereafter SV) and ordinary verbs constructions is linked to their meaning. That is, support verbs are semantically empty, while ordinary verbs are not. Therefore, support verbs are not predicates.

The idiomatic constructions formed by such verbs show a high degree of lexical and syntactic flexibility due to the semantic "emptiness" of the support verb. Such a flexibility of SV idioms is shown by (a) the alternation of support verbs with aspectual variants, (b) the production of causative constructions, (c) the deletion of the support verb itself that can trigger the formation of complex nominal groups and adverbials.

The Lexicon-Grammar of SV idioms (sec. 3.1, Table 2) includes 16 classes for a total of about 3,300 entries. I will present one of the classes defined by the general structure $N_{0}$ essere Prep $C \Omega$, where it is the prepositional complement that is fixed and necessary to sub-categorize a possible further argument $\Omega$, as in the following ${ }^{3}$ :

8. Nelly è al settimo cielo Nelly-is-at-the-seventh-sky

9. Joe è ai ferri corti con Nelly "to be at loggerheads with sb." Joe-is-at-the-short-irons-with-Nelly

In example (8), the fixed prepositional complement $\mathbf{P C}$ does not require a further argument besides the subject, whereas a free prepositional complement $\mathbf{P N}$ is required in the case of (9). Therefore, idioms like (8) and (9) have been listed in two different classes, respectively, EPC and EPCPN, where E indicates the verb essere ('to be'), $\mathbf{P}$ the preposition, $\mathbf{C}$ indicates the constrained noun, and $\mathbf{N}$ the free noun. Figure 2 is an excerpt of the class EPC which includes 500+ entries.

\footnotetext{
${ }^{3}$ The Lexicon-grammar of the French être Prep constructions has been built by Danlos (1988). The Portuguese constructions were analyzed by Ranchod (1983). A first classification of the Italian essere Prep constructions has been built by Vietri (1996). This early classification has been completely revised.
} 


$\begin{array}{cl}\text { - } & \text { chiave } \\ \text { sulla } & \text { corda } \\ \text { alle } & \text { corde } \\ \text { - } & \text { dente } \\ \text { con i } & \text { fiocchi } \\ \text { fuori dai } & \text { gangheri } \\ \text { sul } & \text { lastrico } \\ \text { - } & \text { luogo } \\ \text { - } & \text { mano } \\ \text { - } & \text { nudo } \\ \text { - } & \text { occhio } \\ \text { alle } & \text { porte } \\ \text { sulle } & \text { spine } \\ \text { al } & \text { tappeto } \\ \text { sul } & \text { tappeto } \\ \text { - } & \text { gamba } \\ \text { al } & \text { verde }\end{array}$

Figure 2. The class EPC

The distributional properties [1]-[4] have been previously illustrated (sec. 2, Figure 1). The properties from [5] to [8] indicate the possibility for the EPC constructions to occur with verbs other than essere. The verbs considered are stare ${ }^{4}$, in [5], restare and rimanere ('remain'), in [6], diventare ('become, get') in [7]. The property [8] indicates that a construction with the verb of motion andare ('to go') may be acceptable.

However, the acceptability of all these constructions is lexically dependant, as in the following examples:

10. Nelly $($ sta + resta $+*$ diventa $+v a)$ al settimo cielo $\quad$ "to be in seventh heaven" Nelly-(stays + remains $+*$ becomes + goes)-at-the-seventh-sky

11. Joe $\left({ }^{*}\right.$ sta + resta + diventa $\left.+* v a\right)$ in gamba

"to be smart" Joe-(*stays + remains + becomes $+*$ goes $)$-in-leg

EPC constructions can also enter complex sentence structures with causative verbs (see properties [9]-[10]) such as mandare ('send'), mettere ('to put'), ridurre ('make'), as in the following:

\footnotetext{
${ }^{4}$ I will literally translate this verb as "to stay". However, there is no equivalent in English since this verb is to be found in Romance languages like Italian, Portuguese and Spanish.
} 
12. Joe (mandò $+*$ mise $+*$ ridusse) Nelly al settimo cielo Joe-(sent $+*$ put $+*$ reduced)-Nelly-at-the-seventh-sky

13. Joe (mandò + mise + ridusse) Nelly sul lastrico Joe-(sent + put + reduced)-Nelly-on-the-pavement "to be in seventh heaven"

"to be on the skids"

Finally, property [12] indicates that the link operator (see Gross 1981) avere ('to have') may produce an acceptable sentence, as in (14b):

14a. $\quad$ La situazione in Ukraina è sott'occhio

"to monitor N"

The-situation-in-Ukraine-is-under-eye

14b. Obama ha sott'occhio la situazione in Ukraina

Obama-has-under-eye-the-situation-in-Ukraine

\subsection{The Classes of Idioms with Support Verbs}

Table 2 lists only those classes of SV idioms containing at least 50 idiomatic entries ${ }^{5}$. As a general rule, the classes of idioms with the verb essere start with $\mathbf{E}$, those ones with the verb avere start with $\mathbf{A}$, and finally, those classes involving the verb fare start with $\mathbf{F}$. The only exception is the class PECO which refers to the idioms of comparison where the verb essere is followed by a clause introduced by come ${ }^{6}$.

\begin{tabular}{|l|l|l|r|}
\hline \multicolumn{1}{|c|}{ LG class } & \multicolumn{1}{|c|}{ Sentence structure } & \multicolumn{1}{c|}{ Example } \\
\hline EPC & $\mathrm{N}_{0}$ essere Prep $\mathrm{C}_{1}$ & essere sulle spine \\
\hline EPCModif & $\begin{array}{l}\mathrm{N}_{0} \text { essere Prep Adj } \mathrm{C}_{1} \\
\mathrm{~N}_{0} \text { essere Prep } \mathrm{C}_{1} \text { Adj }\end{array}$ & $\begin{array}{l}\text { essere di vecchio stampo } \\
\text { essere in mani sicure }\end{array}$ & 530 \\
\hline EPCPN & $\mathrm{N}_{0}$ essere Prep $\mathrm{C}_{1}$ Prep $\mathrm{N}_{2}$ & $\begin{array}{l}\text { essere all'oscuro di } N \\
\text { essere ai ferri corti con } N\end{array}$ \\
\hline EPCPC & $\mathrm{N}_{0}$ essere Prep (C Prep C $)_{1}$ & $\begin{array}{l}\text { essere nelle mani di Dio } \\
\text { essere al passo con } \text { i tempi }\end{array}$ & 130 \\
\hline EAPC & $\mathrm{N}_{0}$ essere Adj Prep $\mathrm{C}_{1}$ & non essere dolce di sale & 115 \\
\hline PECO & $\mathrm{N}_{0}$ essere Adj come $\mathrm{C}_{1}$ & essere sordo come una campana & 100 \\
\hline AC & $\mathrm{N}_{\text {avere } \mathrm{C}_{1}}$ & avere polso, avere (buon) occhio & 360 \\
\hline ACA & $\mathrm{N}_{\text {avere } \mathrm{C}_{1} \text { Adj }}$ & avere la memoria corta \\
\hline ACXC & $\mathrm{N}_{0}$ avere $\mathrm{C}_{1}$ Prep $\mathrm{C}_{2}$ & $\begin{array}{l}\text { avere } \text { i nervi a fior di pelle } \\
<=>\mathrm{C}_{1} \text { di } \mathrm{N}_{1} \text { essere Prep } \mathrm{C}_{2}\end{array}$ & 400 \\
\hline ACPN & $\mathrm{N}_{0}$ avere $\mathrm{C}_{1}$ Prep $\mathrm{N}_{2}$ & non avere la testa di $N$ & 180 \\
\hline ACPC & $\mathrm{N}_{0}$ avere $\mathrm{C}_{1}$ Prep $\mathrm{C}_{2}$ & avere il cervello tra le nuvole & 200 \\
\hline FC & $\mathrm{N}_{0}$ fare $\mathrm{C}_{1}$ & fare melina, fare lo gnorri & 300 \\
\hline FCPN & $\mathrm{N}_{0}$ fare $\mathrm{C}_{1}$ Prep $\mathrm{N}_{2}$ & fare le bucce a, fare man bassa di $N$ & 300 \\
\hline FCDC & $\mathrm{N}_{0}$ fare $(\mathrm{C} \text { di })_{1}$ & fare l'arte dei pazzi & 80 \\
\hline FCPC & $\mathrm{N}_{0}$ fare $\mathrm{C}_{1}$ Prep $\mathrm{C}_{2}$ & fare un buco nell' acqua & 220 \\
\hline FPC(PN) & $\mathrm{N}_{0}$ fare Prep $\mathrm{C}_{1}\left(\mathrm{E}+\right.$ Prep $\left.\mathrm{N}_{2}\right)$ & fare sul serio, farsi in quattro per $N$ & 50 \\
\hline Total & & & $\mathbf{3 , 2 3 5}$ \\
\hline
\end{tabular}

Table 2. Idioms with Support Verbs

\footnotetext{
${ }^{5}$ See Vietri (2014, forthcoming) for the complete classification.

${ }^{6}$ For the French classification of idiomatic comparisons see Gross (1984).
} 


\section{Annotating and Parsing Idioms}

The Lexicon-Grammar classes of idioms can be exploited by the hybrid as well as the symbolic approach to Natural Language Processing. Some experimentation in this direction has already been carried out by Machonis (2011), who used NooJ to retrieve and disambiguate English phrasal verbs. NooJ is an NLP application developed by Silberztein (2003) that relies heavily on linguistic resources.

NooJ has been used to carry out experimentation on some of the Lexicon-Grammar classes of Italian idioms. The experimentation, still in progress, concerns the annotation and parsing of idioms. This application allows the construction of lexicons/dictionaries whose entries contain information such as the distributional and syntactic properties indicated in the Lexicon-Grammar classes. The LexiconGrammar classes of idioms can be converted in a NooJ dictionary of idioms. This dictionary, which contains thousands of entries, has to be linked to a grammar that describes the syntactic behaviour of idioms. By applying to a text such a dictionary/grammar pair, NooJ successfully annotates and parses idioms, also in case the constituents Verb + Fixed element(s) are discontinuous. An example of this is the sentence John ha vuotato subito il sacco (lit. John-has-immediately-emptied-the bag, "to spill the beans"), where the underlined adverb occurs between the verb and the fixed object.

However, the current NooJ version does not yet handle easily the syntactic flexibility and the lexical variation of idioms ${ }^{7}$.

\section{Conclusion}

The Lexicon-Grammar classes of idioms are a manually-built linguistic resource that provides information about variation and flexibility of idioms. These classes, being formally coded, constitute an invaluable linguistic resource that can be used for research in (psycho)linguistics, and computational linguistics. The overall classification, as illustrated in Tables 1 and 2, outlines the syntactic patterns of the idiomatic constructions. This is a piece of information that can be regarded as the syntactic map of Italian idioms ${ }^{8}$. Furthermore, the lexico-syntactic information provided by the idioms' classes can also integrate the automatic Machine Translation evaluation methods ${ }^{9}$.

The Lexicon-Grammar classes of idioms can be exploited by the hybrid as well as the symbolic approach to Natural Language Processing. Some experimentation in this direction has already been carried out by Machonis (2011) and by Vietri (2014, forthcoming). Both authors used the knowledgebased system NooJ. On the other hand, Baptista et al. (2014) used the Lexicon-Grammar classes of Portuguese idioms to test the hybrid system STRING.

Further experimentation will be conducted to evaluate the benefit of using the LG distributional and syntactic information in order to extract idioms from corpora. However, very huge corpora (consisting of documents in an informal language style) are needed, together with powerful tools able to perform complex searches on massive textual data.

\section{References}

Anne Abeillé. 1995. The Flexibility of French Idioms: a Representation with Lexicalized Tree Adjoining Grammar. In M. Everaert, E-J. van der Linden, A. Schenk, \& R. Schreuder (Eds.), Idioms: structural and psychological perspectives. Hillsdale, NJ: Lawrence Erlbaum Associates: 15-41.

Jorge Baptista, Anabela Correia, and Graça Fernandes. 2005a. Léxico Gramática das Frases Fixas do Portugués Europeo», Cadernos de Fraseoloxía Galega, 7: 41-53.

Jorge Baptista, Anabela Correia, and Graça Fernandes. 2005b. Frozen Sentences of Portuguese: Formal Descriptions for NLP. Proceedings of the ACL workshop on Multiword Expressions: 72-79.

Jorge Baptista, Nuno Mamede, and Ilia Markov. 2014. Integrating a lexicon-grammar of verbal idioms in a Portuguese NLP system. COST Action IC1207 PARSEME meeting, 10-11 March 2014.

Cristina Cacciari, and Patrizia Tabossi. 1988. The comprehension of idioms. Journal of Memory and Language, 27: 668-683.

\footnotetext{
${ }^{7}$ Cignoni and Coffey (1998) provides the corpus-based results of the lexical variations of idioms.

${ }^{8}$ The complete Lexicon-Grammar classification of Italian idioms will be available at .unisa.it/docenti/simonettavietri/index.

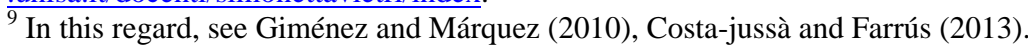


Federica Casadei. 1996. Metafore ed espsressioni idiomatiche. Uno studio semantico sull'italiano. Roma: Bulzoni.

Laura Cignoni, and Stephen Coffey. 1998. A corpus-based study of Italian idiomstic phrases: from citation forms to 'real-life' occurrences. Euralex 1998 Proceedings: 291-300.

Marta Ruiz Costa-jussà, and Mireia Farrús. 2013. Towards human linguistic machine translation evaluation. Literary and Linguistic Computing, Online publication date: 6-Dec-2013.

Cooper Cutting, and Kathryn Bock. 1997. That's the way the cookie bounces: Syntactic and semantic components of experimentally elicited idiom blends. Memory and Cognition, 25:57-71.

Laurence Danlos. 1988. Les phrases à verbe support être Prép. Langages, vol. 23, n. 90: 23-37.

Michele De Gioia. 2001. Avverbi idiomatici dell'italiano. Analisi lessico-grammaticale. Torino: L’Harmattan Italia.

Elisabete Ranchod. 1983. On the support verbs ser and estar in Portuguese. Lingvisticae Investigationes, VII(2): 317-353.

Afsaneh Fazly, Paul Cook, and Susanne Stevenson, S. (2009). Unsupervised Type and Token Identification of Idiomatic Expressions. Computational Linguistics, Vol. 35(1): 62-103.

Christiane Fellbaum. 2011. Idioms and Collocations. In C. Maienborn, K. von Heusinger, \& P. Portner (Eds.), Semantics. An International Handbook of Natural Language Meaning. Vol. 1, Berlin/Boston: De Gruyter Mouton: 441-456.

Richard Fothergill, and Timothy Baldwin. 2012. Combining resources for MWE-token classification. In Proceedings of the First Joint Conference on Lexical and Computational Semantics: 100-104.

Peter Freckleton. 1985. Sentence idioms in English. Working Papers in Linguistics 11, University of Melbourne: 153-168.

Gerald Gazdar, Ewan Klein, Geoffrey Pullum, and Ivan Sag. 1985. Generalized Phrase Structure Grammar, Oxford: Basil Blackwell.

Raymond Gibbs. 1995. Idiomaticity and Human Cognition. In M. Everaert, E-J. van der Linden, A. Schenk, \& R. Schreuder (Eds.), Idioms: structural and psychological perspectives. Hillsdale, NJ: Lawrence Erlbaum Associates: 97-116.

Jesùs Giménez, and Lluìs Màrquez. 2010. Linguistic mesures for automatic machine translation evaluation. Machine Translation, 24:209-240.

Maurice Gross. 1975. Mèthodes en syntaxe. Paris: Hermann.

Maurice Gross. 1979. On the failure of generative grammar. Language, 55(4): 859-885.

Maurice Gross. 1981. Les bases empiriques de la notion de prédicat semantique. Langages, 63, Paris: Larousse: $7-52$.

Maurice Gross. 1982. Une classification des phrases "figées" du français. Revue Québécoise de Linguistique 11.2, Montréal: UQAM: 151-185.

Maurice Gross. 1984. Une famille d'adverbes figés: les constructions comparative en comme. Revue Québécoise de Linguistique 13.2:237-269

Maurice Gross. 1988. Les limites de la phrase figée. Langages 90, Paris: Larousse: 7-22.

Maurice Gross. 1998. La fonction sémantique des verbes supports. Travaux de linguistique, 37, Duculot: Louvain-la-Neuve: 25-46.

Daniela Guglielmo. 2013. Italian Verb-Adverbial Particle Constructions: Predicative Structures and Patterns of Variation. Linguisticae Investigationes, 36.2:229-243.

Zellig Harris. 1982. A Grammar of English on Mathematical Principles, New York: John Winsley and Sons.

Christian Leclère. 2002. Organization of the Lexicon-Grammar of French verbs. Lingvistica Investigationes XX(1): 29-48.

Linlin Li, and Caroline Sporleder. 2009. Classifier Combination for Contextual Idiom Detection Without Labelled Data. Proceedings of the Conference on Empirical Methods in Natural Language Processing (EMNLP 2009) Singapore: 315-323. 
Peter Machonis. 1985. Transformations of verb phrase idioms: passivization, particle movement, dative shift. American Speech 60(4): 291-308.

Peter Machonis. 2011. Sorting Nooj out to take MWE's into account. In K. Vučković, B. Bekavac, \& M. Silberztein (Eds.), Automatic Processing of Various Levels of Linguistic Phenomena. Newcastle upon Tyne: Cambridge Scholars Publishing: 152-165.

Francesca Masini. 2005. Multi-word Expressions between Syntax and the Lexicon: the Case of Italian Verbparticle Constructions.SKY Journal of Linguistics 18, pp. 145-173.

Marjorie McShane, and Sergei Nirenburg. 2014. The Idiom-reference Connection. STEP '08 Proceedings of the 2008 Conference on Semantics in Text Processing, ACL Stroudsburg, PA, USA: 165-177.

Grace Muzny, and Luke Zettlemoyer. 2013. Automatic Idiom Identification in Wiktionary. Proceedings of the Conference on Empirical Methods in Natural language Processing (EMNLP 2013), Seattle, Washington, USA: 1417-1421.

Geoffrey Nunberg, Ivan Sag, and Tom Wasow. 1994. Idioms. Language, Vol. 70, No. 3, 491-538.

Stephen Pulman. 1993. The recognition and Interpretation of idioms, Cacciari C. \& Tabossi, P. (Eds.), Idioms. Processing, Structure, and Interpretation. New Jersey: Lawrence Erlbaum Associates: 249-270.

Ivan Sag, Timothy Baldwin, Francis Bond, Ann Copestake, and Dan Flickinger. 2001. Multiword Expressions: A Pain in the Neck for NLP. Computational Linguistics and Intelligent Text Processing. Berlin Heidelberg: Springer: 1-15.

Max Silberztein. 2003-. NooJ Manual. Available for download at: www.nooj4nlp.net.

Simone Sprenger, Willem Levelt, and Gerard Kempen. 2006. Lexical Access during the Production of Idiomatic Phrases. Journal of Memory and Language, 54: 161-184.

David Swinney, and Ann Cutler. 1979. The access and processing of idiomatic expressions. Journal of Verbal Learning and Verbal Behavior, 18: 523-534

Simonetta Vietri. 1984. Lessico e sintassi delle espressioni idiomatiche. Una tipologia tassonomica in italiano e in inglese. Napoli: Liguori.

Simonetta Vietri. 1996. The Syntax of the Italian verb 'essere Prep', Lingvisticae Investigationes, XX.2: 287350.

Simonetta Vietri. 2014. Idiomatic Constructions in Italian. A Lexicon-Grammar Approach. Linguisticae Investigationes Supplementa, 31. Amsterdam \& Philadelphia: John Benjamins (forthcoming).

Aline Villavicencio, Timothy Baldwin, T., and Benjamin Waldron. 2004. A Multilingual Database of idioms. Proceedings of the Fourth International Conference on language Resources and Evaluation (LREC 2004), Lisbon, Portugal: 1127-30. 